\title{
Korelasi Rasio Aspartate Aminotransferase - Alanine Aminotransferase dengan Profil Hematologi pada Peminum Alkohol
}

\author{
Correlation of Aspartate Aminotransferase - Alanine Aminotransferase Ratio \\ with Hematology Profile in Alcohol Drinker
}

\author{
Lucia Sincu Gunawan* \\ Program Studi D-IV Analis Kesehatan \\ Fakultas Ilmu Kesehatan, Universitas Setia Budi \\ J1. Letjen Sutoyo Mojosongo, Surakarta, Jawa Tengah 57127, Indonesia \\ *Corresponding author: sincugunawan@gmail.com
}

Received: February 12, 2019; Revise: April 15, 2019; Accepted: May 18, 2019

DOI: https://doi.org/10.31001/biomedika.v12i1.465

\begin{abstract}
ABSTRAK
Toksisitas karena alkohol merupakan penyebab ketiga yang paling sering dari penyakit hati dan menjadi peringkat kelima dari sumber beban pembiayaan kesehatan di seluruh dunia. Pada negara maju, alkohol sebagai penyebab utama kejadian sirosis. Seseorang yang mengkonsumsi alkohol secara berlebihan beresiko mengalami komplikasi yang mempengaruhi darah dan sumsum tulang, tempat sel darah diproduksi. Efek buruk alkohol pada produksi sel darah/hematopoiesis terjadi baik langsung maupun tidak langsung. Efek langsung dari konsumsi alkohol berlebihan yaitu efek toksik pada sumsum tulang, prekusor sel darah, sel matur eritrosit, leukosit serta trombosit. Efek tidak langsung konsumsi alkohol yaitu defisiensi nutrisi yang dapat mengganggu produksi dan fungsi berbagai sel darah. Pada penelitian ini dilakukan pemeriksaan kadar aspartate aminotransferase (AST), alanine aminotransferase (ALT), hemoglobin, jumlah eritrosit, jumlah lekosit, jumlah trombosit, hematokrit serta Protrombine Time (PT) dan activated Partial Thromboplastin Time (aPTT) pada 30 laki-laki peminum alkohol yang berusia 20-50 tahun. Dari 30 data responden didapatkan data hemoglobin, jumlah eritrosit, jumlah lekosit, jumlah trombosit, hematokrit, PT, APTT, AST, ALT dan dihitung rasionya. Hasil uji Spearman didapatkan data rasio AST/ALT dengan kadar hemoglobin $(\mathrm{p}=0,741)$, rasio AST dengan jumlah eritrosit $(\mathrm{p}=0,778)$ rasio AST/ ALT dengan jumlah lekosit $(\mathrm{p}=0,472)$, rasio AST/ALT dengan jumlah trombosit $(\mathrm{p}=0,95)$, rasio AST/ALT dengan hematokrit $(\mathrm{p}=0,88)$, rasio AST/ALT dengan PT ( $\mathrm{p}=0,757)$, rasio AST/ALT dengan APTT $(0,352)$. Tidak ada korelasi yang signifikan antara rasio AST/ALT dengan profil hematologi pada peminum alkohol ( $>0,05)$. Pentingnya memperhatikan diet sebagai bagian dari usaha pencegahan penyakit.
\end{abstract}

Kata kunci: alkohol; rasio AST/ALT; profil hematologi 


\begin{abstract}
Toxicity due to alcohol is the most common cause of liver disease and ranks health resources worldwide. In developed countries, alcohol is the main cause of cirrhosis (PalP and Ray S, 2016). People who consumes a lot of alcohol will tend to have haematological dan bone marrow's problems, where blood is produced. The bad effects of alcohol on blood cell production occur directly or indirectly. The direct effects of excessive alcohol consumption are toxic effects on the bone marrow, red blood cells, mature erythrocyte cells, leukocytes and platelets. The indirect effect of alcohol consumption is a nutritional deficiency that can disturb production and function of various blood cells. (Ifeanyi O.E, et al, 2014). In this study, the levels of aspartate aminotransferase (AST), alanine aminotransferase (ALT), haemoglobin, erythrocytescounts, leukocytes counts, platelet counts, haematocrit and Protrombine Time (PT) and Activated Partial Thromboplastin Time (APTT) in 30 alcoholic malesat 20-50 years old were examined. From 30 respondents, haemoglobin data, the number of erythrocytes, the number of leukocytes, the number of platelets, haematocrit, PT, aPTT, $A S T, A L T$ were obtained and the ratio was also calculated. The results of the Spearman test, the AST/ALT ratio data with haemoglobin levels $(p=0.741)$, AST/ALT ratio with erythrocyte count $(p=$ 0.778), AST/ALT ratio with leukocyte count ( $p=0.472)$, AST/ALT ratio with platelet count $(p=0.95)$, AST/ALT ratio with haematocrit $(p=0.88)$, AST/ALT ratio with PT $(p=0.757)$, AST/ALT ratio with aPTT (0.352). There was no significant difference between the AST/ALT ratio and the haematological profile in alcohol drinkers ( $p>0.05$ ). The importance of paying attention to diet as part of a disease prevention.
\end{abstract}

Keywords: alcohol; AST/ALT ratio; hematological parameters

\section{PENDAHULUAN}

Toksisitas karena alkohol merupakan penyebab ketiga yang paling sering dari penyakit hati dan menjadi peringkat kelima dari sumberbeban pembiayaan kesehatan di seluruh dunia. Pada negara berkembang, alkohol sebagai penyebab utama kejadian sirosis(Pal dan Ray, 2016). Minuman beralkohol tradisional merupakan salah satu jenis minuman yang marak di beberapa wilayah di Indonesia. Minuman tradisional dibuat dan dikemas secara sederhana serta sering dijadikan sebagai jamuan di acara adat,misalnya Minuman cap Tikus dari Manado dan Minahasa, Ballo dari Makassar,Sopi dari Maluku dan sekitarnya,Lapen dari Yogyakarta,Arak Bali, Ciu di Jawa Tengah dan sebagainya (BPOM, 2014).

Laporan WHO mengenai alkohol dan kesehatan menyebutkan sebanyak
320.000 orang berusia 15-29 tahun meninggal di seluruh dunia setiap tahun karena berbagai penyebab terkait dengan konsumsi alkohol (WHO, 2014). Konsumsi alkohol secara kronis dalam dosis yang besar dapat menyebabkan kerusakan organ vital seperti otak, liver, lambung, jantung dan meningkatkan resiko terjadinya kanker. Konsumsi dengan jumlah sedang memiliki efek proteksi terhadap penyakit jantung, meski demikian meningkatkan resiko terjadinya diabetes melitus tipe 2 (Ifeanyi et al, 2014).

Abnormalitas histologi terjadi pada penyakit hati alkoholik dari steatosis sampai pada karsinoma hepatoseluler. Pada steatosis hepatis, 90-95\% peminum alkohol berat mengembangkan steatosis makrovesikular pada area centrilobular hati, dan ini belum menimbulkan gejala pada peminum. Meskipun kasus ini masih 
reversible namun $10 \%$ nya tetap berkembang menjadi sirosis. Pada tahap berikutnya hepatitis steatosis berkembang dengan adanya inflamasi dan nekrosis, dimana resiko menjadi sirosis meningkat menjadi $40 \%$. Pada tahap sirosis yang terjadi pada $8-20 \%$ peminum alkohol kronik mengembangkan mikro nodul atau Laennec's Cirrhosis (Pal dan Ray, 2016). Histopatologi penyakit hati alkoholik juga dapat dikarakteristikkan dengan adanya mega mitochondrial dan Mallory hyaline dan degerasi balon dari sel hati (Shah V J, 2015)

Faktor sekunder yang dapat mempercepat progresivitas sirosis yaitu minum secara terus-menerus alkohol dengan jumlah besar tiap harinya dibanding yang minum secara ekstrim tetapi dalam waktu singkat, jenis kelamin wanita yang terkait dengan persentase lemak dan kadar estrogen yang tinggi dan rendahnya kadar gastric alcohol dehydrogenase, kegemukan, polimorfisme genetik dan kondisi komorbid seperti infeksi hepatitis $\mathrm{B}$ atau $\mathrm{C}$, Human Immunodeficiency Virus (HIV) dan hemokromatosis(Pal dan Ray, 2016).

Seseorang yang mengkonsumsi alkohol secara berlebihan beresiko mengalami komplikasi yang mempengaruhi darah dan sumsum tulang, tempat sel darah diproduksi. Efek buruk alkohol pada produksi sel darah atau hematopoesisterjadi baik langsung maupun tidak langsung. Efek langsung dari konsumsi alkohol berlebihan yaitu efek toksik pada sumsum tulang, prekursor sel darah, sel matur eritrosit, lekosit serta trombosit. Efek tidak langsung konsumsi alkohol yaitu defisiensi nutrisi yang dapat mengganggu produksi dan fungsi berbagai sel darah. Kelainan hematologis sering ditemukan pada peminum alkohol. Jumlah sel darah individu merupakan cerminan langsung kesehatan sumsum tulang, sirkulasi dan jaringan (Ifeanyi O.E, et al, 2014).

Sejumlah penelitian menunjukan bahwa etanol juga secara langsung mempengaruhi hemostasis melalui sejumlah mekanisme, termasuk memodulasi faktor koagulasi plasma, fibrinolisis, dan fungsi trombosit. Konsumsi alkohol kronis dapat menjadi predesposisi perdarahan (Laposata, 2005). Alkohol dapat menyebabkan jumlah trombosit yang tidak normal dalam darah (trombositopenia), gangguan fungsi trombosit (trombositopati), dan fibrinolisis berkurang pada sistem pembekuan darah (Harold, 1997).

Beberapa hasil penelitian yang berkaitan dengan penelitian ini juga pernah dilakukan sebelumnya oleh Riany (2013) tentang "Hematologi and Chemistry Test" di Balai Besar Rehabilitasi Badan Narkotika Nasional, Liodo, Jawa Barat. Berdasarkan data pemeriksaan laboratorium 179 responden, didapatkan bahwa 44 (24,58\%)responden, diperoleh hasil pemeriksaan hemoglobin dibawah normal, demikian halnya dengan hasil pemeriksaan eritrosit dan hematokrit, didapatkan bahwa 69 (38,55\%) responden memiliki nilai eritrosit dibawah normal, 36 $(20,11 \%)$ responden memilik nilai hematokrit dibawah normal sedangkan $20,67 \%$ nilai leukosit di atas normal sedangkan $37 \quad(20,67 \%) \quad$ responden memiliki jumlah leukosit diatas normal.Pada penelitian serupa di lakukan oleh Latvala (2004)tentang konsumsi alkohol berlebih sering didapatkan pada 
kasus cytopenia. Penelitian case-control ini menggunakan 144 pasien dengan jumlah sel darah perifer abnormal, selain itu penelitian ini menunjukan peningkatan yang bermakna nilai MCV (Mean Corpuscular Volume) dan $\mathrm{MCH}$ (Mean Corpuscular Hemoglobin) yanglebih sering ditemukan pada alkoholik daripada non-alkoholik.

Penyakit hati akibat alkohol merupakan penyebab kesakitan dan perlemakan hati yang dapat mengarahkan kepadasirosis, kanker hati dan kematian. Konsumsi 40-80 g alkohol perhari pada laki-laki dan 20-40 g per hari pada wanita selama 10-12 tahun merupakan faktor resiko dari penyakit hati alkoholik(Pal dan Ray, 2016). Pada usia yang lebih tua, metabolisme alkohol akan berubah sehingga pada peminum usia lanjut akan lebih sensitif terhadap toksisitas alkohol (Das SK dkk, 2011). Beberapa mekanisme seperti stres oksidatif yang dapat menyebabkan cell injury dengan kerusakan DNA, kelainan fungsi mitokondria, hipoksia, abnormalitas metaboisme metionin, S-Adenosylmethinoine dan folat, kelainan siklus enterohepatik dan fibrosis diajukan sebagai patogenesis terjadinya penyakit hati akibat alkohol (Pal dan Ray, 2016). Hepatitis alkoholik berkaitan dengan peningkatan serum alkaline phospatase, gamma-glutamyl transpeptidase dengan hiperbilirubinemia. Pada hepatitis alkoholik, Aspartate Aminotransferase (AST) kurang dari 300 U/L, dimana Alanine Aminotransferase (ALT) hanya meningkat secara ringan dan rasio AST/ALT $>2$ (PalP dan Ray $\mathrm{S}$, 2016). Menurut Nyblom dkk (2004) dapat disimpulkan sebagian besar pasien dengan konsumsi alkohol tinggi tetapi tanpa penyakit hati yang parah tidak memiliki rasio AST/ALT di atas 1. Rasio AST/ ALT yang tinggi menunjukkan penyakit hati alkoholik lanjut.

Biopsi liver merupakan gold standard untuk diagnosis penyakit hati alkoholik maupun non alkoholik, namun dengan mempertimbangkan etika serta resiko terkait dengan prosedur, maka hal ini jarang dilakukan (Das S K dkk, 2011). Menurut Shah (2015), pemeriksaan laboratorium dapat membantu memperkirakan konsumsi alkohol, yangdapat dirangkum secara bersamaan dengan faktor-faktor demografis lainnya dalam menilai ANI (Alcohol/Nonalcohol Steatohepatitis Index) yang didesain untuk membedakan kedua hal tersebut. Model ini menggunakan MCV (Mean Corpuscular Volume), rasio AST/ ALT, Body Mass Index (BMI) dan jenis kelamin.

Berbeda dengan penelitian yang sebelumnya, pada penelitian ini diperiksa parameter PT dan aPTT selain pemeriksaan darah lengkap. Seperti kita ketahui PT dan aPTT adalah pemeriksaan darah yang terkait hemostasis dimana faktor-faktor pembekuan memegang peranan penting dalam proses fisiologisnya dan sebagian produksinya terkait dengan fungsi hati itu sendiri. Dari latar belakang, peneliti ingin mengetahui korelasirasio AST - ALT dengan profil hematologi pada peminum alkohol.

\section{METODE PENELITIAN}

\section{Alat dan Bahan}

Tabung vakum EDTA, , Jarum disposable, holder, tourniquet, alkohol 
Swab, kasa kering, Centrifuge, darah vena, plasma, Na Citrate.

\section{Prosedur Pemeriksaan}

\section{Prosedur Pengambilan Darah Vena}

a. Pasanglah jarum pada holder, pastikan terpasang erat.

b. Lakukan pendekatan pasien dengan tenang agar pasien nyaman.

c. Identifikasi pasien dengan benar sesuai data

d. Minta pasien meluruskan lengannya, pilih lengan yang banyak melakukan aktifitas.

e. Mintalah pasien untuk mengepalkan tangan.

f. Pasang tali pembendung (turniket) kira-kira $5 \mathrm{~cm}$ di atas lipat siku.

g. Pilih bagian vena mediana cubiti atau vena cephalic. Lakukan perabaan (palpasi) untuk memastikan posisi vena, vena teraba seperti sebuah pipa kecil, elastis dan memiliki dinding tebal. Bersihkan kulit pada bagian yang akan diambil dengan alkohol swab $70 \%$ dan biarkan kering.

h. Tusuk bagian vena dengan posisi lubang jarum menghadap ke atas. Masukkan tabung ke dalam holder dan dorong sehingga jarum bagian posterior tertancap pada tabung, maka darah akan mengalir masuk ke dalam tabung. Tunggu sampai darah secukupnya. (tabung EDTA diikuti tabung $\mathrm{Na}$ Citrate)

i. Lepas turniket dan minta pasien membuka kepalan tangannya. Letakkan kasa kering di tempat suntikan lalu segera lepaskan/tarik jarum. Tekan kapas beberapa saat lalu pasang plester.

\section{Prosedur Pembuatan Plasma}

a. Pusingkan sampel darah selama 10 menit dengan kecepatan $3000 \mathrm{rpm}$.

b. Ambil plasma dengan pipet dan dimasukan dalam tabung yang bersih dan kering.

c. Jika plasma tidak segera di periksa, plasma yang sudah di pisahkan dapat di simpan pada suhu $20^{\circ} \mathrm{C}$ maka plasma akan tahan selama 8 jam (Riswanto, 2013).

\section{Prosedur Protombin Time (manual}

methode: Coatrom M system)

a. Inkubasi reagen Protombin Time( PT )pada suhu $37^{\circ} \mathrm{C}$, selama 10 menit.

b. Pipet $25 \mu 1$ sampel masukan dalam cuvette test. Inkubasi pada suhu $37^{\circ} \mathrm{C}$ 1-2 menit.

c. Tambahkan $50 \mu \mathrm{l}$ reagen Protombin Time( PT ), segera hidupkan stopwatch.

d. Catat cloting time dalam detik.

\section{ProsedurActivated Partial Tromboplastin}

Time (manual methode: M system)

a. $\mathrm{CaCl}_{2}(0,025 \mathrm{M})$ diinkubasi pada suhu $37^{\circ} \mathrm{C}$ tidak lebih dari 10 menit.

b. Pipet $25 \mu \mathrm{l}$ plasma, inkubasi $37^{\circ} \mathrm{C}$ selama 1-2 menit.

c. Tambahkan $25 \mu \mathrm{l}$ reagen Aktivated Partial Tromboplastin Time (APTT) dan inkubasi selama 3 menit pada suhu $37^{\circ} \mathrm{C}$.

d. Tambahkan $25 \mu 1 \mathrm{CaCl}_{2}$ amati cloting time dan catat waktunya dalam detik.

\section{Prosedur Pemeriksaan Menggunakan Hematology Analyzer}

a. Hubungkan kabel power ke stabillisator (stavo). 
b. Hidupkan alat (saklar on/off ada disisi kanan atas alat).

c. Alat akan self check, tulisan "please wait" akan tampil di layar.

d. Alat akan secara otomatis melakukan self check kemudian background check.

e. Pastikan alat pada posisi siap.

f. Sampel darah harus dipastikan sudah homogen dengan antikoagulan.

g. Tekan tombol Whole Blood "WB" pada layar.

h. Tekan tombol ID dan masukkan nomor sampel dan tunggu sampel akan dihisap secara otomatis oleh jarum.

i. Tunggu beberapa saat dan tekan "RUN".

j. Hasil akan muncul pada layar secara otomatis.

k. Cetak hasil pemeriksaan.

\section{HASIL DAN PEMBAHASAN}

Hasil pemeriksaan darah dari 30 lakilaki peminum alkohol yang bersedia sebagai responden didapatkan hasil pemeriksaan darah rutin yang terdiri dari hemoglobin (HGB), jumlah sel darah putih (WBC), jumlah sel darah merah (RBC), jumlah keping darah (PLT), dan hematokrit (HCT), sedangkan hasil Mean Corpuspular Volume (MCV), Mean Corpuscular Hemoglobin (MCH), dan Mean Corpuscular Hemoglobin Concentration (MCHC) didapatkan dari rumus yang terkait dengan Hemoglobin, Hematokrit, dan Jumlah Eritrosit. Selain itu juga didapatkan data pemeriksaan Protrombine Time (PT) dan activated Partial Tromboplastin Time (aPTT).
Tabel 1 menunjukan bahwa kadar hemoglobin normal berjumlah 28 orang (93,3\%), kurang dari normal sebanyak 1 orang $(3,3 \%)$, lebih dari normal sebanyak 1 orang $(3,3 \%)$, jumlah lekosit normal berjumlah 21 (70\%), kurang dari normal 1 orang $(3,3 \%)$, lebih dari normal 8 orang $(26,7 \%)$, jumlah eritrosit normal 23 orang $(76,7)$, lebih dari normal 5 orang $(16,7 \%)$, kurang dari normal 2 orang (6.6\%), kadar hematokrit normal berjumlah 25 orang $(83,3 \%)$, kurang dari normal 1 orang $(3,3 \%)$, lebih dari normal 4 orang $(13,3 \%)$, dan jumlah trombosit semuanya normal $(100 \%)$.

Penurunan kadar hemoglobinterjadi pada satu responden. Kejadian anemia pada peminum alkohol sering terjadi dengan gambaran MCV meningkat, yang dikaitkan dengan defisiensi nutrisi seperti asam folat. Pada responden A, gambaran indeks eritrositnya $\mathrm{MCV}$ dan $\mathrm{MCHC}$ kurang dari normal, sehingga disimpulkan sebagai anemia mikrositik hipokromik, seperti yang sering terjadi pada anemia defisiensi besi ataupun anemia pada penyakit kronik, variasi yang dapat juga terjadi pada peminum alkohol. Efek mengkonsumsi alkohol pada sel eritrosit atau sel darah merah berupa anemia ringan yang terjadi karena anemia defisiensi asam folat, anemia defisiensi zat besi dan dapat juga terjadi perdarahan pada lambung. Pada pasien alkoholik, anemia defisiensi zat besi sulit didiagnosa karena gejalanya dapat ditutupi oleh gejala defisiensi nutrisi yang lain (defisiensi asam folat) atau bersama dengan penyakit hati dan kondisi inflamasi lain yang berkaitan dengan alkoholik (Ballard, 1997).Peningkatan MCV dapat digunakan sebagai prosedur screening untuk mendeteksi 
penyalahgunaan alkohol. Peningkatan MCV menggambarkan beratnya penyakit hati yang mendasarinya, dan pada penelitian yang lain adanya korelasi yang sangat kuat antara MCV dan jumlah konsumsi alkohol (Das SK dkk, 2011).Penentuan jenis anemia berdasarkan morfologi eritrosit dapat dikonfirmasi dengan apusan darah tepi.

Tabel 1. Hasil Pemeriksaan Darah Rutin

\begin{tabular}{|c|c|c|c|c|c|c|}
\hline \multicolumn{2}{|c|}{ NO KODE SAMPEL } & $\begin{array}{l}\text { HGB } \\
(g / d l)\end{array}$ & $\begin{array}{l}\text { WBC } \\
\left(10^{3} / u l\right)\end{array}$ & $\begin{array}{c}\mathrm{RBC} \\
\left(10^{6} / u l\right)\end{array}$ & $\begin{array}{c}\text { PLT } \\
\left(10^{3} / u l\right)\end{array}$ & $\begin{array}{r}\mathrm{HCT} \\
(\%)\end{array}$ \\
\hline 1 & A & 11.3 & 5.2 & 4.48 & 266 & 36.7 \\
\hline 2 & B & 15.6 & 6.2 & 4.94 & 252 & 44.1 \\
\hline 3 & $\mathrm{C}$ & 15.2 & 11.4 & 5.04 & 426 & 43.8 \\
\hline 4 & $\mathrm{D}$ & 15.7 & 7.9 & 5.42 & 229 & 46.3 \\
\hline 5 & $\mathrm{E}$ & 20.6 & 10.6 & 7.47 & 232 & 61.5 \\
\hline 6 & $\mathrm{~F}$ & 15.8 & 11.2 & 5.04 & 324 & 47.0 \\
\hline 7 & $\mathrm{G}$ & 17.4 & 9.2 & 6.33 & 251 & 52.6 \\
\hline 8 & $\mathrm{H}$ & 16.3 & 7.9 & 4.76 & 309 & 44.6 \\
\hline 9 & $\mathrm{I}$ & 16.3 & 5.4 & 5.27 & 242 & 47.6 \\
\hline 10 & $\mathrm{~J}$ & 15.9 & 8.1 & 5.12 & 320 & 46.7 \\
\hline 11 & $\mathrm{~K}$ & 16.3 & 9.8 & 6.33 & 261 & 47.6 \\
\hline 12 & $\mathrm{~L}$ & 15.2 & 13.0 & 4.88 & 394 & 44.2 \\
\hline 13 & $\mathrm{M}$ & 17.1 & 5.6 & 5.32 & 218 & 48.4 \\
\hline 14 & $\mathrm{~N}$ & 15.4 & 9.5 & 5.13 & 231 & 45.9 \\
\hline 15 & $\mathrm{O}$ & 16.3 & 7.6 & 5.28 & 299 & 46.6 \\
\hline 16 & $\mathrm{P}$ & 15.1 & 10.6 & 4.97 & 185 & 43.5 \\
\hline 17 & $Q$ & 16.2 & 8.5 & 5.23 & 174 & 46.6 \\
\hline 18 & $\mathrm{~L}$ & 14.9 & 8.1 & 4.85 & 145 & 42.4 \\
\hline 19 & $\mathrm{M}$ & 16.3 & 9.9 & 6.31 & 256 & 47.6 \\
\hline 20 & $\mathrm{~N}$ & 15.2 & 4.9 & 4.77 & 280 & 42.5 \\
\hline 21 & $\mathrm{O}$ & 16.2 & 8.7 & 4.91 & 229 & 46.5 \\
\hline 22 & $\mathrm{P}$ & 15.0 & 8.9 & 5.14 & 414 & 45.2 \\
\hline 23 & $Q$ & 15.7 & 7.3 & 5.15 & 335 & 44.7 \\
\hline 24 & $\mathrm{R}$ & 15.9 & 11.8 & 6.28 & 222 & 47.3 \\
\hline 25 & $\mathrm{~S}$ & 15.9 & 8.1 & 5.43 & 356 & 47.0 \\
\hline 26 & $\mathrm{~T}$ & 14.9 & 8.9 & 4.48 & 378 & 44.1 \\
\hline 27 & $\mathrm{U}$ & 16.9 & 15.0 & 5.30 & 246 & 50.4 \\
\hline 28 & $\mathrm{~V}$ & 16.1 & 7.5 & 5.22 & 278 & 47.1 \\
\hline 29 & $\mathrm{~W}$ & 15.3 & 13.4 & 4.60 & 260 & 43.0 \\
\hline 30 & $\mathrm{X}$ & 16.3 & 9.1 & 5.29 & 302 & 47.6 \\
\hline & Nilai Normal & $13-18$ & $5-10$ & $4.5-5.5$ & $150-450$ & $40-48$ \\
\hline
\end{tabular}


Tabel 2. Distribusi Interpretasi Hasil Pemeriksaan Darah Rutin

\begin{tabular}{ccccccccccc}
\hline & \multicolumn{2}{c}{ HGB } & WBC & \multicolumn{3}{c}{ RBC } & \multicolumn{3}{c}{ PLT } & \multicolumn{3}{c}{ HCT } \\
\cline { 2 - 14 } & JML & $\%$ & JML & $\%$ & JML & $\%$ & JML & $\%$ & JML & $\%$ \\
\hline$<$ NORMAL & 1 & 3,3 & 1 & 3,3 & 1 & 3,3 & 0 & 0 & 1 & 3,3 \\
\hline NORMAL & 28 & 93,3 & 21 & 70 & 24 & 80 & 0 & 0 & 25 & 83.3 \\
\hline$>$ NORMAL & 1 & 3,3 & 8 & 26,7 & 5 & 16,7 & 30 & 100 & 4 & 13,3 \\
\hline JUMLAH & 30 & 100 & 30 & 100 & 30 & 100 & 30 & 100 & 30 & 100 \\
\hline
\end{tabular}

Peningkatan kadar hemoglobin, jumlah eritrosit, dan hematokrit tampak pada responden E, yang lebih sering dikenal dengan nama polisitemia. Polisitemia dapat terjadi karena kelainan primer yang disebut dengan polisitemia vera akibat kelainan genetik yang digambarkan dengan aktivitas sumsum tulang yang meningkat khususnya dalam eritropoesis, dan dapat juga disebabkan akibat kelainan sekunder yang terkait dengan hipoksia jaringan, peningkatan hormon eritropoetin dan rangsangan pembentukan eritrosit yang berlebihan. Polisitemia sekunder juga sering tampak pada perokok berat dimana hipoksia jaringan akan meningkatkan pembentukan sel darah merah.

Peningkatan jumlah sel darah putih dari harga normal yang disebut dengan lekositosis, terjadi pada 8 responden, dimana 1 responden mengalami leukopenia atau kurangnya jumlah sel darah putih. Lekositosis dikaitkan dengan adanya peradangan ataupun infeksi baik akut maupun kronik. Peningkatan jumlah lekosit dapat mempunyai makna yang berbeda melihat hasil dari hitung jenis lekosit. Lekopenia dapat dikaitkan dengan adanya infeksi virus dan bakteri tertentu, pengaruh obat-obatan, penekanan produksi pada sumsum tulang akibat alkohol dan lain-lain.
Tidak tampak perubahan parameter jumlah trombosit pada 30 responden yang diperiksa. Berbeda dengan penelitian yang dilakukan oleh Ifeanyi dkk (2014), alkohol menekan produksi trombosit dan menyebabkan trombositopenia yang mengakibatkan abnormalitas hemostasis dan menghambat terjadinya agregasi trombosit. Di lain sisi, terjadi peningkatan aktivasi trombosit dalam merespon thrombin pada semua level konsumsi alkohol. Peningkatan aktivitas trombosit dapat berkontribusi dalam terjadinya kematian mendadak terkait pada reaksi withdrawal atau pada peminum ekstrim. Pada penelitian yang dilakukan oleh Das SK dkk (2011) hemoglobin, jumlah sel eritrosit, hematokrit, jumlah limfosit dan jumlah trombositsecara signifikan menurun, dimana $\mathrm{MCV}$ dan $\mathrm{MCH}$ meningkat secara signifikan.

Berdasarkan tabel 4 distribusi interpretasi hasil pemeriksaan Protrombin Time dan activated Partial Tromboplastin Time pada 30 responden peminum alkohol di didapatkan nilai pemeriksaan sebagai berikut: Protrombin Time 2 orang (6,7\%) didapatkan hasil pemeriksaan normal dan 28 orang $(93,3 \%)$ didapat hasil yang memendek. Dan pada pemeriksaan activated Partial Tromboplastin Time 30 orang (100\%) nilai pemeriksaan yang memendek. Berbeda dengan penelitian yang dilakukan oleh Das SK dkk (2011), 
PT secara signifikan memanjang pada penderita penyakit hati alkoholik, sehingga pemanjangan waktu PT biasanya mengindikasikan penurunan fungsi hati yang berat.

Protrombin Time dan activated Partial Tromboplastin Time adalah pemeriksaan yang digunakan untuk menilai fungsi hemostasis terkait dengan faktor-faktor koagulasi/ pembekuan darah. Prothrombin time (PT) untuk menilai faktor-faktor koagulasi di jalur ekstrinsik dan bersama, sedangkan activated Partial Tromboplastin Time (aPTT) untuk menilai faktor-faktor koagulasi di jalur intrinsik dan bersama. Protombin Time adalah uji koagulasi yang sering dilakukan. Prothrombin Time menilai kemapuan faktor koagulasi ekstrinsik, yaitu faktor I, faktor II, faktor V, faktor VII, dan faktor $X$. Reagen yang digunakan adalah tromboplastin jaringan dan kalsium terionisasi. Apabila ditambahkan ke plasma sitrat, reagen-reagen ini akan mengantikan tromboplastin jaringan untuk mengaktifkan faktor X dengan keberadaan faktor VII tanpa melibatkan trombosit atau prokoagulan jalur intrinsik. Untuk mendapatkan hasil Protombin Time normal, plasma harus mengandung paling sedikit $100 \mathrm{mg} / \mathrm{dl}$ fibrinogen dan kadar faktor VII, X, V, dan protombin yang memadai. Nilai normalnya adalah $11-13$ detik (tergantung metode dan reagen yang digunakan) (Riswanto, 2013). Pemeriksaan activated Partial Tromboplastin Time bertujuan untuk menilai aktifitas faktor koagulasi intrinsik, yaitu faktor VIII, IX, XI, XII, pre-kalikrein, kinogen, $\mathrm{x}, \mathrm{v}$, protombin dan fibrinogen. Nilai normal tergantung jenis reagen dan metode pemeriksaan yang digunakan. Tetapi bila hasilnya $>7$ detik dari nilai normal, maka hasil pemeriksaan itu dianggap abnormal (Riswanto, 2013).

Faktor koagulasi, terkhususnya fibrinogen dan faktor VII, merupakan faktor yang terkait dengan aterosklerosis. Adanya hubungan yang kurang signifikan antara konsumsi alkohol dan konsentrasi fibrinogen pada laki-laki usia di atas 45 tahun. Pada semua strata usia dan jenis kelamin, bukan peminum alkohol mempunyai kadar fibrinogen yang tertinggi, dimana subyek yang mengkonsumsi 40 sampai dengan 59 g etanol tiap harinya mempunyai kadar fibrinogen yang terendah. Peningkatan konsumsi alkohol dari kurang dari 1 kali per hari menjadi lebih 5 kali per hari menyebabkan peningkatan faktor IX tanpa mempunyai efek kepada faktor VII, di sisi lain menurunkan kadar fibrinogen plasma dan konsentrasi von Willbrand's factor(vWf). Pada penelitian yang dilakukan Ridker dkk menunjukkan korelasi positif antara pola konsumsi alkohol dengan konsentrasi t-PA (tissue Plasminogen Activator) dimana kadar tertinggi t-PA ditemukan pada peminum alkohol 2 atau lebih perharinya dan kadar terendah didapatkan pada subyek yang jarang minum atau tidak pernah, tanpa ditemukannya peningkatan PAI-1 (Plasminogen Activator Inhibitor 1). Pada penelitian yang lain seperti pada penelitian di Northwick Park Heart Study, mengindikasikan aktivitas fibrinolitik yang lebih tinggi pada peminum dibandingkan bukan peminum yang diukur dengan pemeriksaan clot lysis time sebagai salah satu penanda aktivitas fibrinolisis (Laposata, 2005). 
Tabel 3. Hasil Pemeriksaan Protombin Time dan activated Partial Tromboplastin Time

\begin{tabular}{|c|c|c|c|}
\hline NO & $\begin{array}{l}\text { KODE } \\
\text { SAMPEL }\end{array}$ & $\begin{array}{c}\text { Protombin Time } \\
\text { (detik) }\end{array}$ & $\begin{array}{c}\text { activated Partial } \\
\text { TromboplastinTime (detik) }\end{array}$ \\
\hline 1 & $\mathrm{~A}$ & 12,4 & 16,6 \\
\hline 2 & B & 9,4 & 11,8 \\
\hline 3 & $\mathrm{C}$ & 13,8 & 13,3 \\
\hline 4 & $\mathrm{D}$ & 10,1 & 6,7 \\
\hline 5 & $\mathrm{E}$ & 6,5 & 17,4 \\
\hline 6 & $\mathrm{~F}$ & 4,1 & 5,6 \\
\hline 7 & $\mathrm{G}$ & 4,8 & 15,9 \\
\hline 8 & $\mathrm{H}$ & 7,1 & 13,7 \\
\hline 9 & $\mathrm{I}$ & 6,6 & 11,8 \\
\hline 10 & $\mathrm{~J}$ & 7,6 & 12,8 \\
\hline 11 & $\mathrm{~K}$ & 7,6 & 5,3 \\
\hline 12 & $\mathrm{~L}$ & 7,0 & 4,5 \\
\hline 13 & $\mathrm{M}$ & 6,8 & 8,0 \\
\hline 14 & $\mathrm{~N}$ & 6,3 & 16,2 \\
\hline 15 & $\mathrm{O}$ & 5,5 & 16,9 \\
\hline 16 & $\mathrm{P}$ & 9,9 & 13,3 \\
\hline 17 & $\bar{Q}$ & $\overline{5,6}$ & 14,2 \\
\hline 18 & $\mathrm{~L}$ & 9,4 & 13,5 \\
\hline 19 & $\mathrm{M}$ & 6,7 & 12,6 \\
\hline 20 & $\mathrm{~N}$ & 5,4 & 12,6 \\
\hline 21 & $\mathrm{O}$ & 10,3 & 7,0 \\
\hline 22 & $\mathrm{P}$ & 6,6 & 5,1 \\
\hline 23 & $\mathrm{Q}$ & 6,9 & 11,6 \\
\hline 24 & $\mathrm{R}$ & 5,4 & 9,1 \\
\hline 25 & $\mathrm{~S}$ & 7,6 & 9,6 \\
\hline 26 & $T$ & $\overline{5,4}$ & 7,7 \\
\hline 27 & $\overline{\mathrm{U}}$ & 4,8 & 6,2 \\
\hline 28 & $\mathrm{~V}$ & 7,4 & 7,5 \\
\hline 29 & $\mathrm{~W}$ & 3,0 & 7,3 \\
\hline 30 & $\mathrm{X}$ & 8,9 & 6,1 \\
\hline \multicolumn{2}{|c|}{ Nilai Normal } & $11-13$ & $35-45$ \\
\hline
\end{tabular}


Tabel 4. Distribusi Interpretasi Hasil PemeriksaanProtombin Time (PT) Dan activatedPartial Tromboplastin Time (aPTT)

\begin{tabular}{lcccc}
\hline \multirow{2}{*}{ NILAIPEMERIKSAAN } & \multicolumn{2}{c}{$P T$} & \multicolumn{2}{c}{$a P T T$} \\
\cline { 2 - 5 } & Jumlah & $\%$ & Jumlah & $\%$ \\
\hline$<$ Normal/memendek & 28 & 93,3 & 30 & 100 \\
\hline Normal & 2 & 6,7 & - & - \\
\hline$>$ Normal /memanjang & - & - & - & - \\
\hline Total & 30 & 100 & 30 & 100 \\
\hline
\end{tabular}

Pemendekan waktu PT dan atau dan ALT sering dianggap sebagai enzim aPTT meningkatkan resiko terjadinya trombus dan emboli pada responden. Beberapa penelitian yang sebelumnya melaporkan peningkatan aktivitas fibrinolitik setelah konsumsi alkohol. Yang terbaru, studi lebih terkontrol telah menunjukkan bahwa alkohol mengurangi fibrinolisis sehari setelah konsumsi alkohol atau selama konsumsi alkohol berkepanjangan. Observasi ini menunjukkan bahwa pecandu alkohol mungkin berisiko tinggi mengalami trombosis. Gangguan yang disebabkan oleh alkohol pada sistem pembekuan darah atau fibrinolitik dapat menimbulkan konsekuensi medis yang serius. Alkohol dapat mengganggu beberapa proses yang dapat menyebabkan penurunan jumlah trombosit dalam darah (trombositopenia), gangguan fungsi trombosit (trombositopati), dan gagalnya proses fibrinolisis. Efek ini dapat menyebabkan konsekuensi medis yang serius seperti peningkatan resiko stroke (Harold S, 1997).

Dua enzim yang paling sering berkaitan dengan kerusakan hepatoseluler adalah aminotransferase yang mengatalisis pemindahan reversibel satu gugus amino antara sebuah asam amino dan sebuah asam alfa keto, yakni alanin aminotransferase (ALT) dan aspartate aminotransferase (AST). Walaupun AST hati karena tingginya konsentrasi kedua enzim pada hepatosit, namun hanya ALT yang spesifik, AST terdapat di miokardium, otot rangka, otak, dan ginjal. Angka hasil pemeriksaan aktivitas AST dibagi aktivitas ALT dalam sampel serum disebut dengan rasio de Ritis. Rasio ini digunakan untuk membedakan berbagai penyakit dengan peningkatan dengan derajad yang berbeda. Perlemakan hati karena alkohol dapat meningkatkan ALT dan AST secara ringan yaitu 1-3 x normal atau bahkan normal. Hepatitis alkoholik berkaitan dengan peningkatan serum alkaline phospatase, gamma-glutamyl transpeptidase dengan hiperbilirubinemia. Pada hepatitis alkoholik, Aspartate Aminotransferase (AST) kurang dari 300 $\mathrm{U} / \mathrm{L}$, dimana Alanine Aminotransferase (ALT) hanya meningkat secara ringan dan rasio AST/ALT >2 (Pal, $\mathrm{P}$ dan Ray $\mathrm{S}$, 2016). Menurut Shah (2015), pemeriksaan laboratorium dapat membantu memperkirakan konsumsi alkohol dan beberapa dapat dirangkum secara bersamaan dengan faktor-faktor demografis dalam menilai ANI (Alcohol/nonalcohol Steatohepatitis Index) yang didesain untuk membedakan kedua hal tersebut. Model ini menggunakan MCV (Mean Corpuscular Volume), rasio AST/ ALT, Body Mass Index (BMI) dan jenis kelamin. 
Dari 30 responden sejumlah 4 orang (13\%) mempunyai kadar ALT yang meningkat dan 26 orang $(87 \%)$ dengan kadar ALT yang normal. Sejumlah 3 orang $(10 \%)$ mempunyai kadar AST yang meningkat dan 27 (90\%) mempunyai kadar yang normal. Peningkatan kadar ALT dan AST yang orang tampak pada responden sebesar 1-3 kali nilai rujukan.

Tabel 5. Hasil Pemeriksaan SGOT, SGPT, dan Rasio SGOT/SGPT

\begin{tabular}{|c|c|c|c|c|}
\hline NO & KODE SAMPEL & ALT & AST & RASIO AST/ALT \\
\hline 1 & A & 62 & 46 & 0,74 \\
\hline 2 & $\mathrm{~B}$ & 20 & 21 & 1,05 \\
\hline 3 & $\mathrm{C}$ & 14 & 17 & 1,21 \\
\hline 4 & $\mathrm{D}$ & 16 & 24 & 1,50 \\
\hline 5 & $E$ & 37 & 23 & 0,62 \\
\hline 6 & $\mathrm{~F}$ & 22 & 30 & 1,36 \\
\hline 7 & $\mathrm{G}$ & 66 & 40 & 0,61 \\
\hline 8 & $\mathrm{H}$ & 14 & 21 & 1,50 \\
\hline 9 & $\mathrm{I}$ & 27 & 27 & 1,00 \\
\hline 10 & $\mathrm{~J}$ & 17 & 36 & 2,12 \\
\hline 11 & $\mathrm{~K}$ & 15 & 27 & 1,80 \\
\hline 12 & $\mathrm{~L}$ & 21 & 21 & 1,00 \\
\hline 13 & $\mathrm{M}$ & 22 & 28 & 1,27 \\
\hline 14 & $\mathrm{~N}$ & 17 & 25 & 1,47 \\
\hline 15 & $\mathrm{O}$ & 15 & 25 & 1,67 \\
\hline 16 & $\mathrm{P}$ & 37 & 25 & 0,68 \\
\hline 17 & $Q$ & 19 & 20 & 1,05 \\
\hline 18 & $\mathrm{~L}$ & 10 & 30 & 3,00 \\
\hline 19 & $\mathrm{M}$ & 16 & 94 & 5,88 \\
\hline 20 & $\mathrm{~N}$ & 76 & 25 & 0,33 \\
\hline 21 & $\mathrm{O}$ & 14 & 30 & 2,14 \\
\hline 22 & $\mathrm{P}$ & 17 & 21 & 1,24 \\
\hline 23 & $\mathrm{Q}$ & 18 & 30 & 1,67 \\
\hline 24 & $\mathrm{R}$ & 23 & 30 & 1,30 \\
\hline 25 & $\mathrm{~S}$ & 20 & 59 & 2,95 \\
\hline 26 & $\mathrm{~T}$ & 22 & 31 & 1,41 \\
\hline 27 & $\mathrm{U}$ & 18 & 38 & 2,11 \\
\hline 28 & $\bar{V}$ & 29 & 15 & 0,52 \\
\hline 29 & $\mathrm{~W}$ & 15 & 31 & 2,07 \\
\hline \multirow[t]{2}{*}{30} & $\mathrm{X}$ & 23 & 27 & 1,17 \\
\hline & Nilai Normal & $0-35$ & $3-45$ & $<1$ \\
\hline
\end{tabular}


Tabel 6. Distribusi Interpretasi Hasil Pemeriksaan AST dan ALT

\begin{tabular}{lcccc}
\hline \multirow{2}{*}{ NILAIPEMERIKSAAN } & \multicolumn{2}{c}{$A L T$} & \multicolumn{2}{c}{$A S T$} \\
\cline { 2 - 5 } & Jumlah & $\%$ & Jumlah & $\%$ \\
\hline Kurang dari normal & - & - & - & - \\
\hline Normal & 26 & 87 & 27 & 90 \\
\hline Lebih dari normal & 4 & 13 & 3 & 10 \\
\hline Total & 30 & 100 & 30 & 100 \\
\hline
\end{tabular}

Tabel 7. Distribusi Rasio AST/ALT Responden Peminum Alkohol

\begin{tabular}{lcc}
\hline \multirow{2}{*}{ NILAIPEMERIKSAAN } & \multicolumn{2}{c}{ Rasio $A S T / A L T$} \\
\cline { 2 - 3 } & Jumlah & $\%$ \\
\hline Kurang dari 1 & 6 & 20 \\
\hline $1-2$ & 17 & 57 \\
\hline Lebih dari 2 & 7 & 23 \\
\hline Total & 30 & 100 \\
\hline
\end{tabular}

Tabel 8. Nilai Rata-Rata Rasio AST/ALT dan Profil Hematologi Pada Peminum Alkohol

\begin{tabular}{|l|c|c|}
\hline \multicolumn{1}{|c|}{ Parameter } & Mean / nilai rata-rata \pm SD & Jumlah Subyek \\
\hline Rasio AST/ALT & $1,54 \pm 1,07$ & 30 \\
\hline Hemoglobin & $15,88 \pm 1,42$ & 30 \\
\hline Jumlah Eritrosit & $5,32 \pm 0,66$ & 30 \\
\hline Jumlah Lekosit & $8,8 \pm 2,37$ & 30 \\
\hline Jumlah Trombosit & $276,86 \pm 70,99$ & 30 \\
\hline Hematokrit & $46,38 \pm 4,11$ & 30 \\
\hline PT & $7,393 \pm 2,31$ & 30 \\
\hline APTT & $10,95 \pm 4,02$ & 30 \\
\hline
\end{tabular}

Sejumlah 30 responden, didapatkan hasil rasio AST/ALT kurang dari 1 sebanyak 6 orang $(20 \%)$, rasio antara 1 sampai dengan 2 sebanyak 17 orang (57\%) dan rasio di atas 2 sebanyak 7 orang (23\%). Pada penelitian yang dilakukan oleh Nyblom H dkk (2004) menyimpulkan rasio AST/ALT yang tinggi, lebih dari 1 menunjukkan penyakit alkoholik yang lanjut. Sedangkan pada penelitian yang dilakukan oleh Pal P dan Ray S (2016) menggunakan rasio lebih dari 2 untuk membedakan kasus hepatitis alkoholik dan non alkoholik. Pada hepatitis alkoholik, Aspartate Aminotransferase (AST) kurang dari $300 \mathrm{U} / \mathrm{L}, \quad$ dimana Alanine Aminotransferase hanya meningkat secara ringan dan rasio AST/ALT $>2$. Hal ini menunjukkan pada sebagian besar(80\%) responden mengalami penyakit hati alkoholik. Sejumlah 30 data responden didapatkan data hemoglobin, jumlah eritrosit, jumlah lekosit, jumlah trombosit, hematokrit, PT, APTT, AST, ALT dan 
dihitung rasionya. Normalitas data diuji dengan Shapiro Wilk dengan $p<0,05$, sehingga dilakukan transformasi data. Transformasi data tidak mendapatkan data yang terdistribusi normal, maka digunakan Spearman Correlation test. Dari hasil uji Spearmen yang dapat dilihat pada Tabel 9, maka tampak tak ada korelasi antara rasio AST/ALT dengan kadar hemoglobin $(p=0,741)$, rasio AST dengan jumlah eritrosit $(p=0,778)$ rasio AST/ ALT dengan jumlah lekosit $(\mathrm{p}=0,472)$, rasio AST/ALT dengan jumlah trombosit $(p=0,95)$, rasio AST/ALT dengan hematokrit $(\mathrm{p}=0,88)$, rasio AST/ALT dengan PT $(p=0,757)$, rasio AST/ALT dengan APTT (0,352). Kecukupan ukuran sampel dan tersedianya kelompok kontrol dapat meningkatkan validitas pemeriksaan. Teknik pengambilan sampel yang tepat dapat meningkatkan kualitas sampel sehingga mendukung validitas penelitian.

Tabel 9. Tabel Korelasi Spearman Antara Rasio AST/ALT dengan Hemoglobin, Jumlah Eritrosit, Jumlah Lekosit, Jumlah Trombosit, Hematokrit, PT dan APTT

\begin{tabular}{|c|c|c|c|c|c|c|c|c|c|c|}
\hline \multicolumn{11}{|c|}{ Correlations } \\
\hline & & & $\begin{array}{c}\text { RASIO } \\
\text { ASTIALT }\end{array}$ & $\begin{array}{c}\text { HEMOGLOBI } \\
\mathrm{N}\end{array}$ & ERITROSIT & LEKOSIT & TROMBOSIT & HEMATOKRIT & $\begin{array}{c}\text { PROTROMBI } \\
\mathrm{N}\end{array}$ & APTT \\
\hline \multirow[t]{24}{*}{ Spearman's rho } & \multirow[t]{3}{*}{ RASIO AST/ALT } & Correlation Coefficient & 1.000 & .063 & .054 & .142 & .012 & .029 & .059 & -.176 \\
\hline & & Sig. (2-tailed) & & .741 & .778 & .472 & .950 & .880 & .757 & .352 \\
\hline & & $\mathrm{N}$ & 30 & 30 & 30 & 28 & 30 & 30 & 30 & 30 \\
\hline & \multirow[t]{3}{*}{ HEMOGLOBIN } & Correlation Coefficient & .063 & 1.000 & $.727^{\mathrm{xx}}$ & .077 & -.251 & $.884^{\pi x}$ & -.252 & .069 \\
\hline & & Sig. (2-tailed) & .741 & & .000 & .695 & .181 & .000 & .180 & .716 \\
\hline & & $\mathrm{N}$ & 30 & 30 & 30 & 28 & 30 & 30 & 30 & 30 \\
\hline & \multirow[t]{3}{*}{ ERITROSIT } & Correlation Coefficient & .054 & $.727^{x x}$ & 1.000 & .241 & -.248 & $.861^{x x}$ & -.148 & -.023 \\
\hline & & Sig. (2-tailed) & .778 & .000 & & .217 & .187 & .000 & .435 & .905 \\
\hline & & $\mathrm{N}$ & 30 & 30 & 30 & 28 & 30 & 30 & 30 & 30 \\
\hline & \multirow[t]{3}{*}{ LEKOSIT } & Correlation Coefficient & .142 & .077 & .241 & 1.000 & .028 & .252 & -.221 & -.222 \\
\hline & & Sig. (2-tailed) & .472 & .695 & .217 & & .888 & .196 & .259 & .255 \\
\hline & & $\mathrm{N}$ & 28 & 28 & 28 & 28 & 28 & 28 & 28 & 28 \\
\hline & \multirow[t]{3}{*}{ TROMBOSIT } & Correlation Coefficient & .012 & -.251 & -.248 & .028 & 1.000 & -.187 & -.011 & -.281 \\
\hline & & Sig. (2-tailed) & .950 & .181 & .187 & .888 & & .321 & .955 & .133 \\
\hline & & $\mathrm{N}$ & 30 & 30 & 30 & 28 & 30 & 30 & 30 & 30 \\
\hline & \multirow[t]{3}{*}{ HEMATOKRIT } & Correlation Coefficient & .029 & $.884^{2 \pi}$ & $.861^{\pi x}$ & .252 & -.187 & 1.000 & -.304 & -.131 \\
\hline & & Sig. (2-tailed) & .880 & .000 & .000 & .196 & .321 & & .102 & .489 \\
\hline & & $\mathrm{N}$ & 30 & 30 & 30 & 28 & 30 & 30 & 30 & 30 \\
\hline & \multirow[t]{3}{*}{ PROTROMBIN } & Correlation Coefficient & .059 & -.252 & -.148 & -.221 & -.011 & -.304 & 1.000 & .032 \\
\hline & & Sig. (2-tailed) & .757 & .180 & .435 & .259 & .955 & .102 & & .867 \\
\hline & & $\mathrm{N}$ & 30 & 30 & 30 & 28 & 30 & 30 & 30 & 30 \\
\hline & \multirow[t]{3}{*}{ APTT } & Correlation Coefficient & -.176 & .069 & -.023 & -.222 & -.281 & -.131 & .032 & 1.000 \\
\hline & & Sig. (2-tailed) & .352 & .716 & .905 & .255 & .133 & .489 & .867 & \\
\hline & & $N$ & 30 & 30 & 30 & 28 & 30 & 30 & 30 & 30 \\
\hline
\end{tabular}

\section{KESIMPULAN}

Tidak adanya korelasi yang signifikan antara rasio AST/ALT dengan profil hematologi pada peminum alkohol ( $\mathrm{p}>$ $0,05)$

\section{DAFTAR PUSTAKA}

Bakta , I.M. 2006. Hematologi Klinik Ringkas. Jakarta: ECG

Ballard, H.S. 1997. The Hematological Complications of Alcoholism. Alcohol Health \& Research Word, Vol 21 (1): 4252

Bain, B.J. 2014. Hematologi. Jakarta: penerbit ECG BPOM RI. 2014. Topik Sajian Utama : Memiliki Regulasi Minuman Beralkohol di Indonesia.InfoPOM. Vol . 15 No. 3 Mei Juni 2014 
Das, S. K, Mukherjee, S, Vasudevan, D M, Balakrishnan V. 2011. Comparison of hematological parameters in patients with non-alcoholic fatty liver disease and alcoholic liver disease.Singapore Medical Journal 52(3): 175

Harold, S. 1997. "The Hematological Complications of Alcoholism". Alkohol Health \& Research World.

Ifeannyi, O.E; Ndukaku,O.Y; Ndubuisi, O.T; Kalu, O.N; Obioma, E. 2014. Some Haematological and Biochemical Parameters of Chronic Alcoholics in Umuahia, Abia State, Nigeria.Research Journal of Pharmaceutical, Biological and Chemical Scienses. 5(2): 831-836

Kiswari, D.R. 2014. Hematologi dan Tranfusi. Jakarta: Peneribit Erlangga

Laposata, M dan Salem, O R. 2005. "Effects of Alkohol on Hemostasis". American Socienty for Clinical Pathology

Oduola, T, Adeosun, O G, Oduola T A, Agbaje N.R, Raheem Z A. 2005. Drinking pattern : biochemical and haematological findings in alcohol consumers in lle-lfe, Nigeria. African Journal of Biotechnology Vol 4(11) pp 1304-1308

Pal, P. dan Ray, S. 2016. Alcoholic Liver Disease : A Comprehensive Review. European Medical Journal. 1(2) : 85-92

Pratama, 2006. Penetapan Kadar Etanol Pada Minuman Beralkohol Secara Kromatografi Gas. Skripsi. Universitas Indonesia.Depok

Rahajuningsih, D.S. 2009. Hemostasis Dan Trombosis. Jakarta: Balai Peneribit FKUI

Riswanto. 2013. Pemeriksaan Laboratorium Hematologi. Yogyakarta.: Alfamedia Dan Kanal medika

Robbins. 2007. Buku Ajar Patologi. Volume 1. Edisi 7. Buku Kedokteran. Jakarta:ECG

Shah, V. H. 2015. Managing alcoholic liver disease. Clinical and Moleculer Hepatology; 21:212-219

Sofro, A.S.M. 2012 .Darah ,Yogyakarta: Pustaka Pelajar

Tjay, T.H. and Rahardja, K., 2007. Obat Obat penting, Jakarta, Elex Media Komputindo. 